\title{
New old stones at Antiochia in Rough Cilicia: A novel city name and a proposed visit by Hadrian and Sabina
}

\author{
Michael Hoff ${ }^{1}$, Rhys Townsend ${ }^{2}$, and Timothy Howe ${ }^{3}$ \\ ${ }^{1}$ School of Art, Art History \& Design, University of Nebraska-Lincoln \\ $<$ mhoff1@unl.edu> \\ ${ }^{2}$ Department of Visual and Performing Arts, Clark University \\ $<$ rtownsend@clarku.edu> \\ ${ }^{3}$ Department of History, St. Olaf College \\ $<$ howe@stolaf.edu>
}

\begin{abstract}
This article considers the evidence of newly discovered inscriptions from Antiochia ad Cragum in western Rough Cilicia and proposes two distinct observations: one, the city had an additional civic name different from that which is most commonly known; and two, the emperor Hadrian and Sabina may have visited the city and region during their journey from Egypt to Athens in $131 \mathrm{CE}$.
\end{abstract}

Keywords: Antiochia ad Cragum, Rough Cilicia, Antiochus IV of Commagene, Hadrian, Sabina, Francis Beaufort

\section{Introduction}

The excavations at the Roman-era city of Antiochia ad Cragum on the Turkish south coast have been ongoing since 2005, and since the beginning inscriptions have been discovered that shed helpful light on the history of the city. However, 2018 was an exceptional year for epigraphical discoveries in which several inscribed stones were found that challenge long-held notions about the city and add significantly to the historical record. Two of the inscriptions found that year offer the first instances on stone of a novel toponymic epithet for the city rather than the commonly held toponymic ad Cragum. The editiones principes of both, dealing solely with physical autopsy and textual reconstruction, have appeared separately. ${ }^{1}$ The current paper addresses the historical context of these inscriptions - civic nomenclature and possible imperial patronage in particular. The first section considers the formation of the city under Antiochus IV of Commagene and how these new inscriptions and known civic coinage reveal a different name than that by which the city is commonly known. In the second section, epigraphical evidence from one of the inscriptions is used to build a circumstantial case for a proposed visit to the city by Hadrian and Sabina in $131 \mathrm{CE}$ as part of their westward journey from Egypt to Athens.

\section{The city name of Antiochia in Rough Cilicia}

In 1810 Francis Beaufort, commanding the frigate HMS Fredrikssteen, was ordered to survey the coastlines of the southeastern Aegean Sea and eastward along the south Turkish coast of the Mediterranean. The British Admiralty, engaged in the Napoleonic

Hoff and Howe 2020. 
Wars, was keenly interested in charting potential harborages that could be used to shelter enemy ships, especially in case of French adventurism. Beaufort departed Smyrna late in the sailing season of 1811 and wintered at Malta before resuming his voyage in spring 1812. This mission afforded him the opportunity to explore the coastline of Asia Minor for something more than a military purpose, principally archaeological exploration. The observations and documentation resulting from the two-year mission served as the first major European survey of the ancient remains on these coasts. ${ }^{2}$ Such a survey would naturally dovetail with strategic naval observations, since advantageous anchorages would probably have changed little since antiquity. It should therefore be expected that Beaufort came to Asia Minor armed with geographical texts such as Strabo and Ptolemy; indeed, references to them are peppered throughout his account.

Beaufort's report of his arrival in late (?) spring 1812 at Antioch in western Rough Cilicia is instructive. Following his visit to Selinos, as he is traveling east, he writes: "We next came to the ruins of an ancient town, which, I apprehend, must have been the Antiochia ad Cragum of Ptolemy." ${ }^{3}$ Ptolemy (5.7.2) is the first ancient source (late 2nd c. CE) to mention

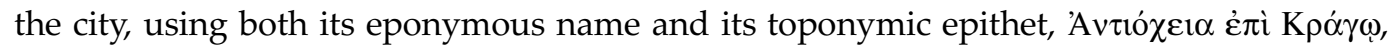
by which in its Latinized form, Antiochia ad Cragum, the city is commonly known today. However, he situates Antioch between Selinos (modern Gazipaşa) and Nephelis, even though the city lies east of Nephelis, not west (Figs. 1-2). Moreover, the next city Ptolemy lists moving eastward is Anemurion, while Beaufort - correctly - gives Charadros as the next coastal city he comes to while sailing eastward. Beaufort, therefore, is not following Ptolemy blindly, for otherwise he would have confused Charadros with Nephelis. It is possible that Beaufort also had a copy of the Stadiasmus maris magni, a 3rd-c. CE maritime survey of Mediterranean shores, which not only gives the sequence of cities correctly but provides fairly accurate distances between them. ${ }^{4}$

When Rudolf Heberdey and Adolf Wilhelm visited Antioch in 1891, they appear to have accepted Beaufort's designation implicitly: "Die eigentliche Stadt Antiocheia am Kragos, von Beaufort nur kurz erwähnt, liegt bedeutend höher." ${ }^{5}$ Subsequently, Roberto

2 Beaufort 1817. In addition to his military and archaeological interests, Beaufort was engaged in meteorological studies; the Beaufort Scale, which categorizes wind forces according to observed conditions at sea or on land, is named after him, as is the Beaufort Sea, an outlying sea of the Arctic Ocean, located north of Alaska and the Yukon.

3 Beaufort 1817, 185. Accompanying Beaufort on the survey was the 23-year-old Robert Cockerell, the antiquarian and future architect, who noted in his own separate account the following: "After passing a promontory we came opposite to a rocky ridge sloping rapidly to the sea, on which was a fortress, answering to Strabo's Antiochetta on the Cragus." Since Strabo mentions only "Cragus," not Antiochia or Antiochetta, it is possible that Cockerell instead meant to say Ptolemy. For Cockerell's account, see his memoir published nearly a century later: Cockerell 1903; for the visit to Antioch see 180-81. In Beaufort's account (Beaufort 1817, 185), he claims that he was unable to render a proper visit to the site, but Cockerell reports that he alone made the hike up the steep hill, nearly $300 \mathrm{~m}$ high, where he viewed much of the preserved standing architecture, especially the remains of the Great Bath (181).

4 On the Stadiasmus maris magni and bibliography, see Arnaud 2017, 15-50; for the relevant text of the Stadiasmus, see Müller 1855, 486, §200. For a discussion of the Stadiasmus's description of the coastal sites of western Rough Cilicia, see Karamut and Russell 1999, 365.

$5 \quad$ Heberdey and Wilhelm 1896, 152. 


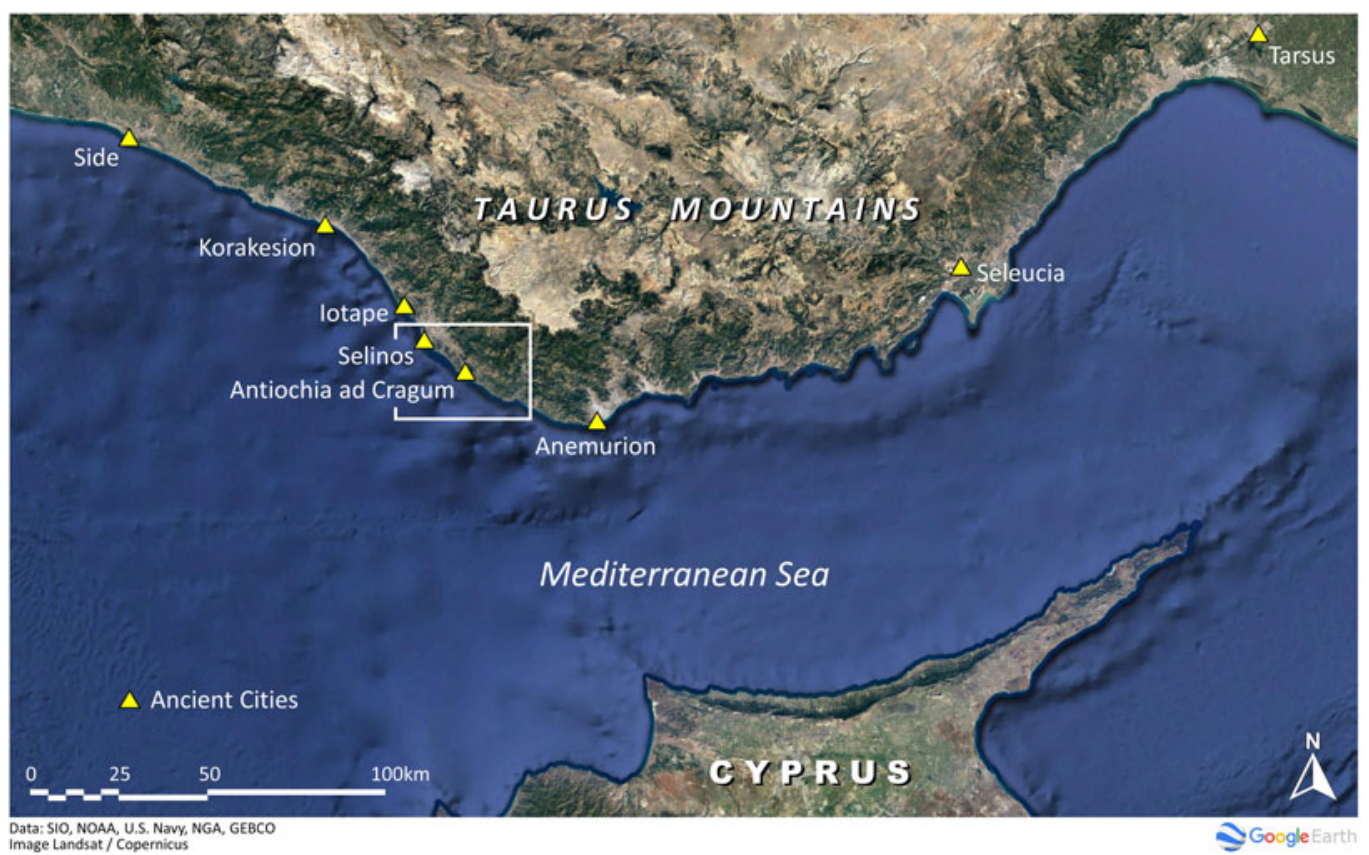

Fig. 1. Major coastal sites of southern Turkey from Pamphylia to Cilicia. (Map by B. Cannon.)

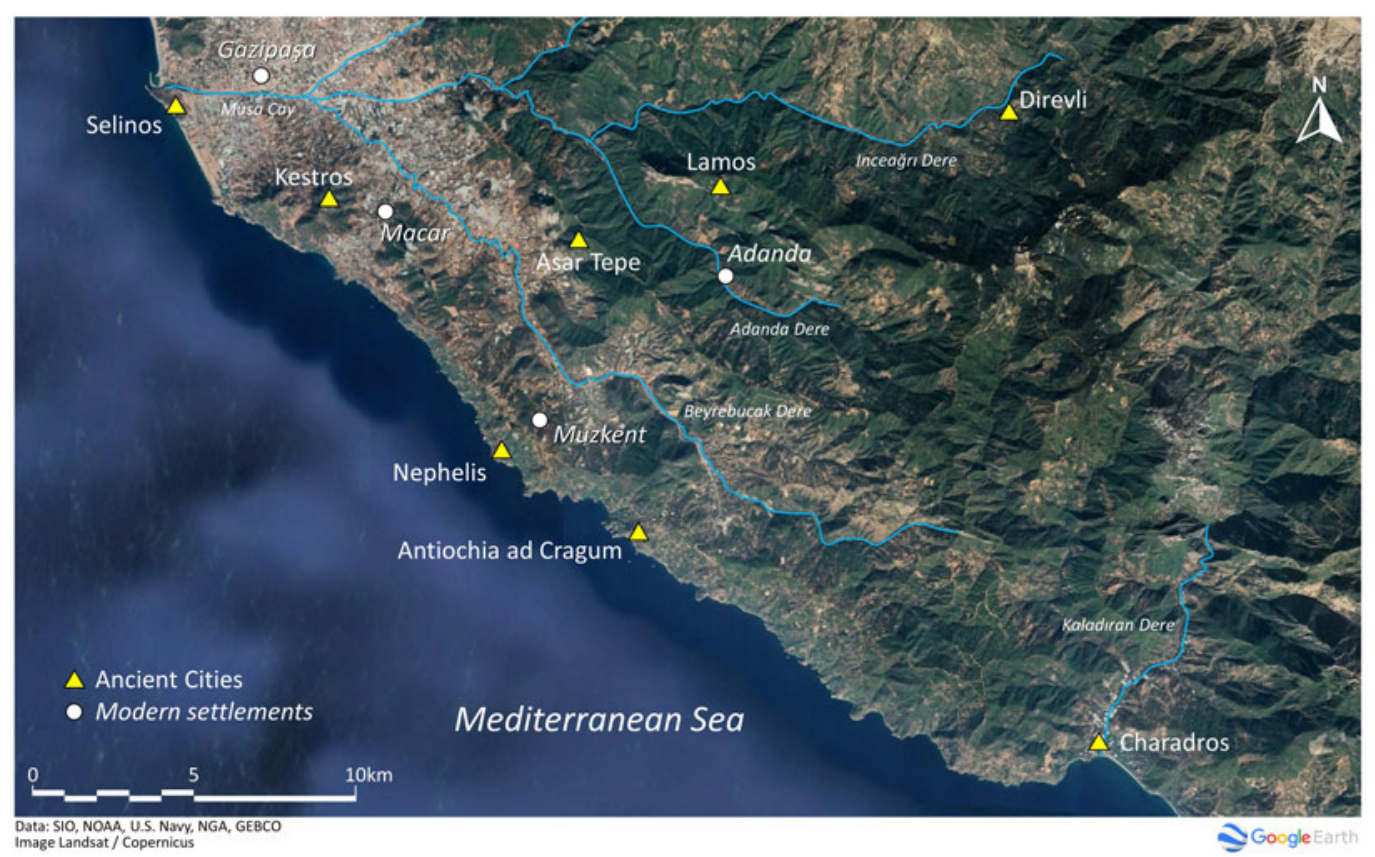

Fig. 2. Western Rough Cilicia. Ancient cities and major river basins. (Map by B. Cannon.)

Paribeni and Pietro Romanelli mentioned an inscription "rinvenuta ad Antiochia ad Cragum (Günei) da Heberdey e Wilhelm."' ${ }^{6}$ By the time George Bean and Terence

$6 \quad$ Paribeni and Romanelli 1914, 172. 
Mitford arrived for their epigraphical survey of Rough Cilicia in the early 1960s, they too accepted the identification, citing Heberdey and Wilhelm only in passing. ${ }^{7}$ In fact, since most archaeological and historical references to the site use the Ptolemaic formula, Beaufort's use of it - and the Latin epithet ad Cragum - seems to mark the origin of the commonly accepted name of the city today. But from where did Ptolemy derive the name, and is it the city's original, official title?

The formal foundation of the Roman-era city and the origin of the eponymous name Antiochia belong to the mid-1st c. CE (see below). Occupation of the site, however, can be traced back to the Cilician pirates who preyed upon shipping in the coastal waters in the 2nd and 1st c. BCE. The earliest reference to the location is made by Strabo (early 1st c. CE). In his description of the coast of western Cilicia, he refers to a place east of Selinos as the "Kragos, a rock which is precipitous all around and near the sea." ${ }^{8}$ Appian (writing in the 2nd c. CE) mentions that the Cilician pirates operated bases on the Kragos and Antikragos when Pompey arrived to deal with the pirate threat in 67 BCE, the two redoubts serving as their "largest citadels" in Cilicia. ${ }^{9}$ Ptolemy's and Appian's toponyms both match Strabo's, Appian adding the name "Antikragos," which corresponds closely to the topography. The three sources appear to be referring to the same place, with the latter two relying on Strabo or another, even earlier account for the nomenclature.

Strabo's and Appian's "Kragos" should be identified as the acropolis of the later, Roman-era city of Antioch in the modern village of Güney where the Antiochia ad Cragum Archaeological Research Project has been conducting excavations since 2005 (Figs. 3-4). ${ }^{10}$ Excavations carried out atop the acropolis, known locally as Kaleş Tepe, have uncovered a Late Roman/Byzantine Christian complex that adjoins a church. Archaeological remains of any pre-Christian structures have so far eluded detection, although some walls contain large blocks that could have been utilized in pre-Roman constructions. The Antikragos is identified as the promontory that juts out into the sea c. $1 \mathrm{~km}$ west of the Kragos (Fig. 5). The promontory is ringed with a Byzantine-era fortification wall, but no standing structures datable to the Hellenistic or Roman era are observable, and preliminary pedestrian surveys conducted in the late 1990s failed to locate pre-Roman concentrations of habitation. ${ }^{11}$

Such lack of remains is unsurprising given the transitory nature of pirate activity. Buildings were not likely to be constructed of durable stone, but instead would be built of more perishable materials such as wood, which would naturally leave less visible footprints. Plutarch (Pomp. 28.1) in fact informs us that the pirates maintained fortresses in the higher elevations of the Taurus mountains, where their families and treasures could be relatively safe. Appian (Mith. 96) also speaks of the "mountain Cilicians." Such higher-altitude

Bean and Mitford 1965, 34.

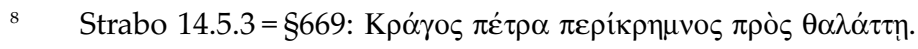

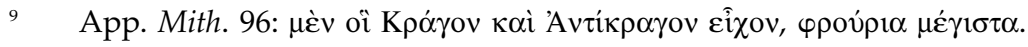

10 The excavation is a research program under the aegis of the University of Nebraska-Lincoln; see Hoff et al. 2015 with bibliography.

11 More intensive pedestrian survey is scheduled for the 2021 season. The pedestrian survey was conducted under the auspices of the Rough Cilicia Survey Project (RCSP); for a summary of the RCSP work, see Rauh et al. 2009, 274. 


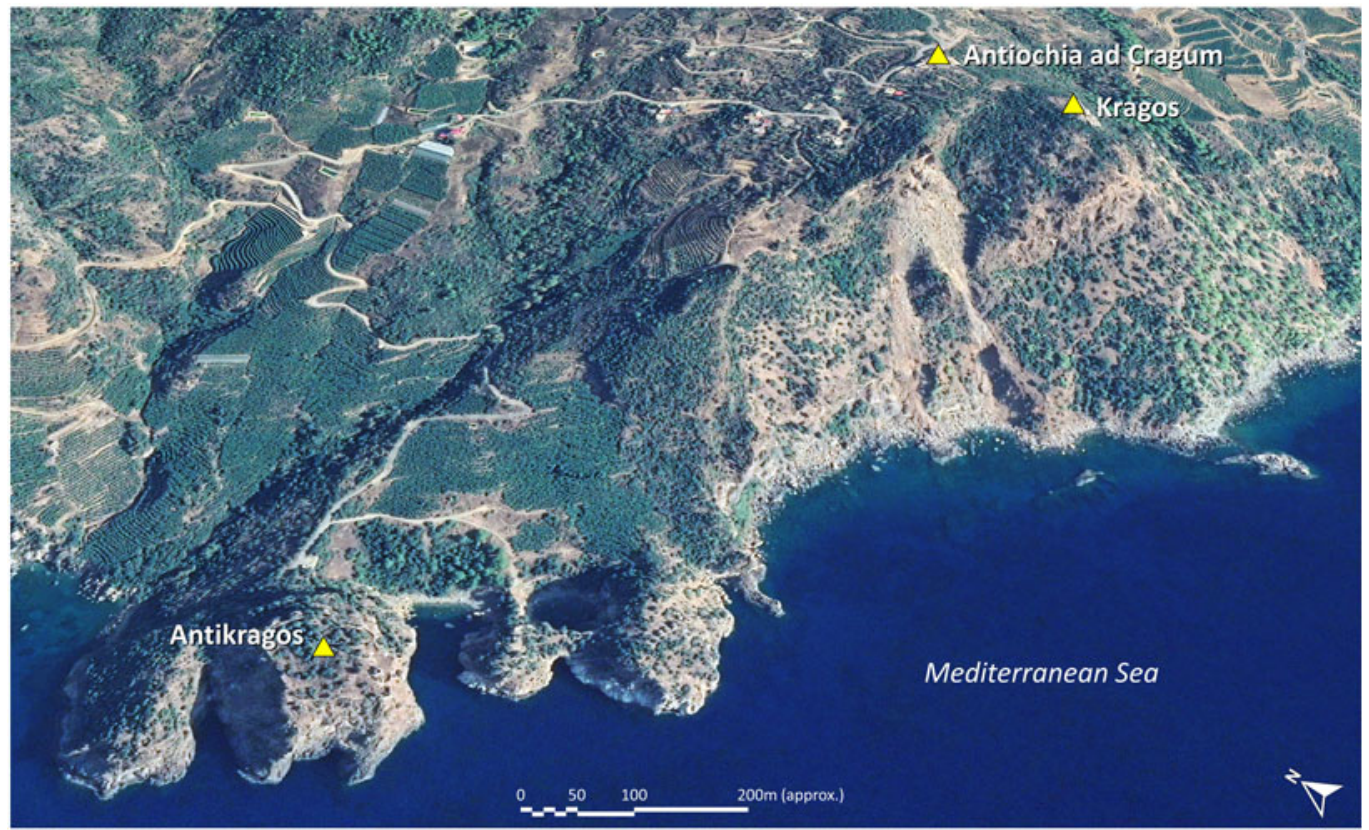

O2020 Google
Image O 2020 CNES / Airtus
02020 Basarsoft

YGoogle

Fig. 3. Aerial view of Antikragos (left) and Kragos (right). (Google, (c) 2020 CNES/Airbus, Basarsoft.)

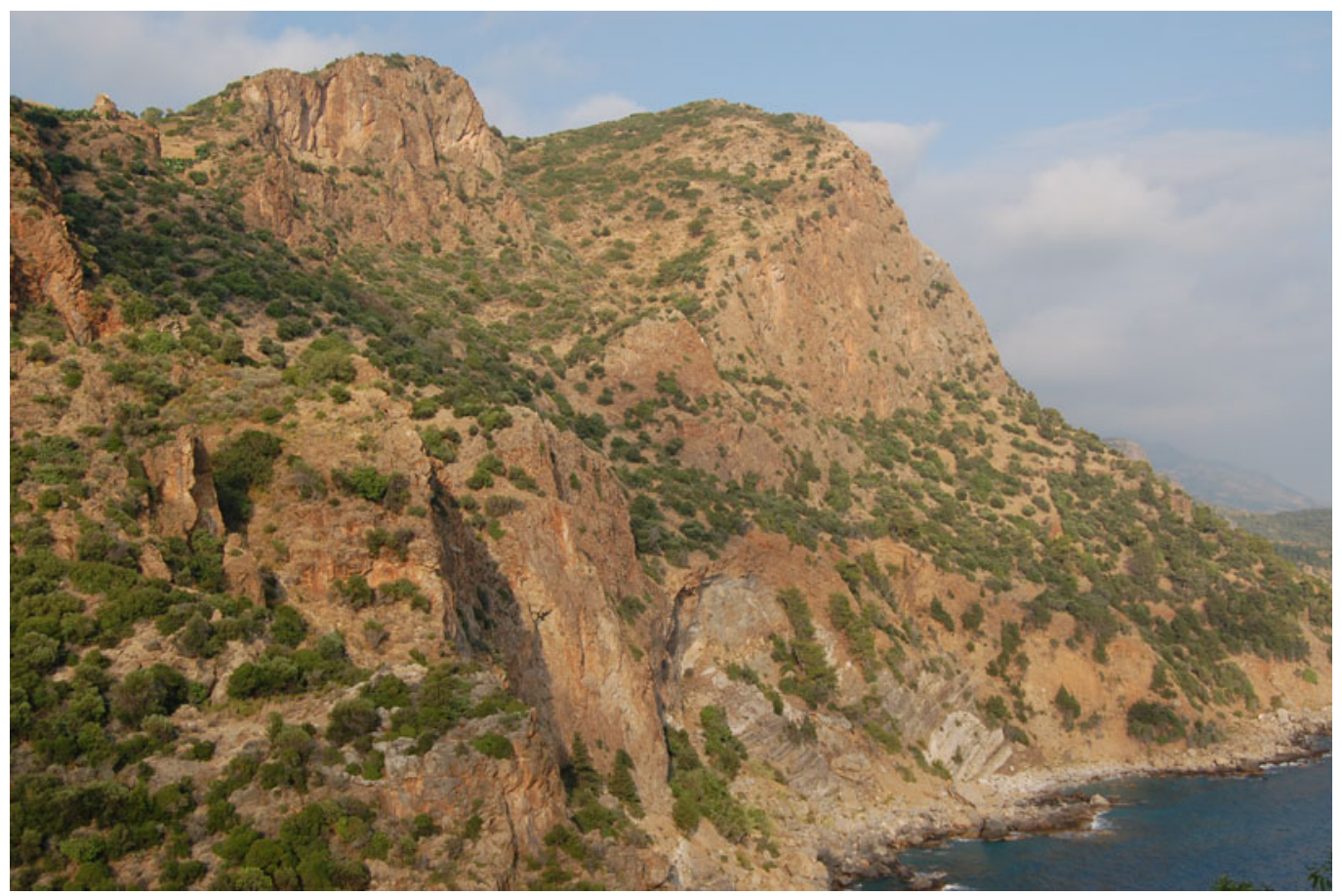

Fig. 4. General view of Kragos, from the west. (Courtesy ACARP archives.) 


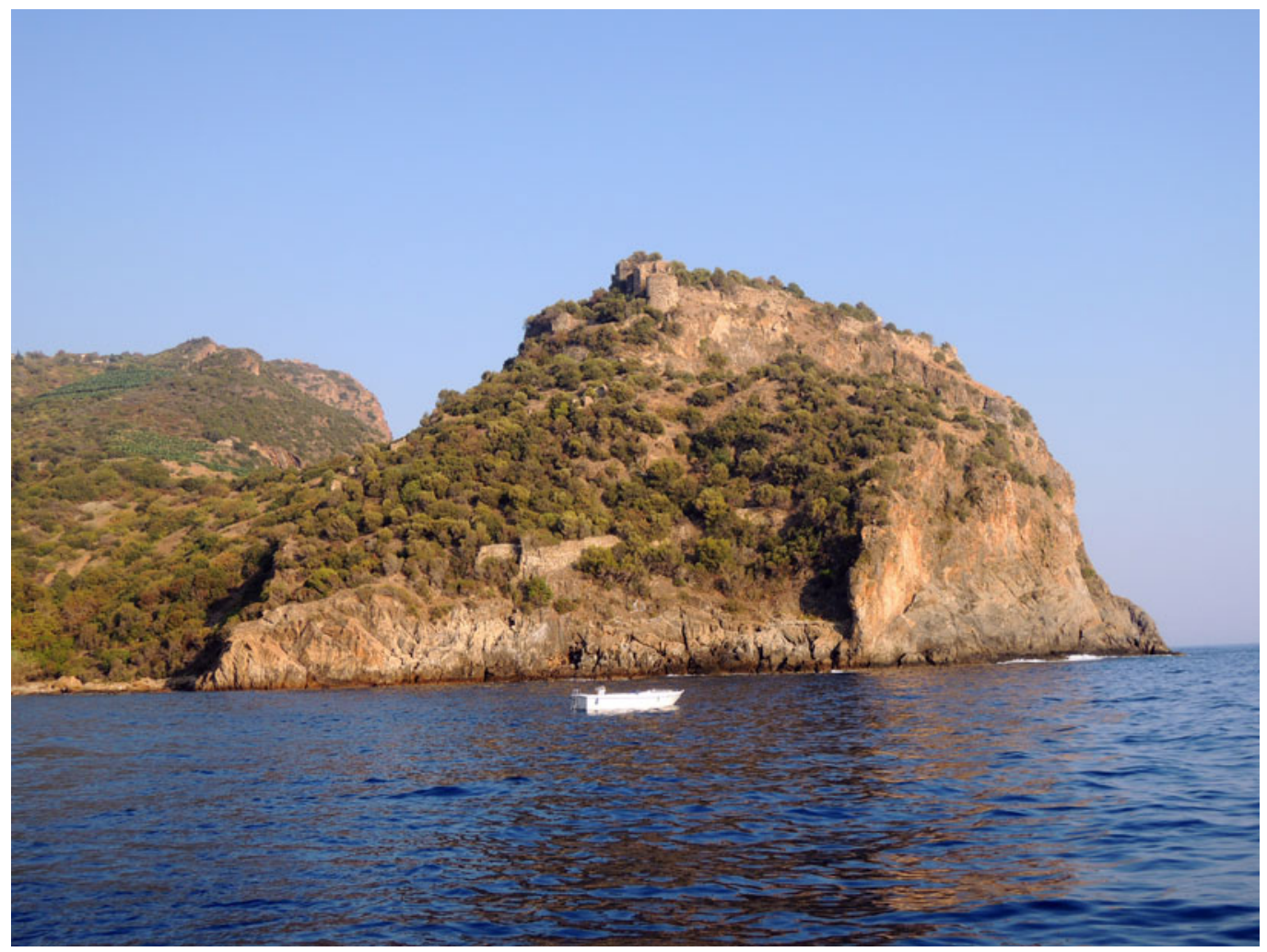

Fig. 5. General view of Antikragos, from the northwest. (Courtesy R. Frank.)

sites probably served as their more permanent domiciles. In 2004-5, underwater survey was undertaken in the small bight adjacent to the Antikragos that is assumed to have served as the anchorage of the Roman city. This investigation did produce several finds that may be associated with the period of pirate activity: they include a fragment of a Will Type 10 amphora that is generally dated to the 1st c. BCE and a bronze socket decorated in the form of the winged horse Pegasus, a type attached to the ends of ship timbers. Wood material recovered from the socket indicates an approximate calibrated radiocarbon date of $125 \mathrm{BCE}$, which would place the socket during the pirates' heyday. ${ }^{12}$ While not conclusive, these stray finds offer tantalizing evidence that the anchorage, and thus likely the site as well, were occupied at the time that Appian places the pirates here.

After Pompey defeated the pirates at Korakesion (modern Alanya) in 67 BCE, he relocated many of them throughout Cilicia, mainly in Cilicia Pedias to the east. Appian claims (Mith. 96) that the pirates who were ensconced within the citadels of the Kragos and the Antikragos were among the first to surrender. Can we assume, then, that the former pirate facilities and the site were completely abandoned until Antioch was founded in the mid-1st c. CE? Given that it was useful at least as an anchorage, possibly some sort of occupation continued during this transitional period. Strabo's use of a toponym to identify the locale, rather than a place name as with all the other settlements he cites in this region $(14.5 .3-6=\S 669-71)$, perhaps indicates that the Kragos was a well-known landmark even if it lacked a formal designation. 
Following Pompey's operations, all of Cilicia technically became Roman territory. In $36 \mathrm{BCE}, \mathrm{M}$. Antonius ceded to Cleopatra the territory of Rough Cilicia (Cilicia Tracheia), whose cedar forests and other timber could be used to augment her fleet that was to be used against Octavian at Actium. ${ }^{13}$ After Octavian defeated Antonius and Cleopatra in 31 BCE, he gave Rough Cilicia to Amyntas, king of Galatia and Pisidia. Following the death of Amyntas in $25 \mathrm{BCE}$, its rule was first given to Archelaus I of Cappadocia, then to his son, Archelaus II (Cass. Dio 54.9.1-2). Rome's policy toward problematic areas often involved the use of client-kings, quasi-independent warlords whose role was to serve as surrogates to moderate peripheral areas while Rome's military could be engaged in more significant operations elsewhere. ${ }^{14}$ In keeping with this policy, after Archelaus II died in $38 \mathrm{CE}$, Caligula awarded his friend and confidant Antiochus IV of Commagene the territory of Cilicia Tracheia and at least part of Lycaonia ${ }^{15}$ in $38 \mathrm{CE}^{16}$ However, Antiochus's relationship with the mercurial Gaius quickly soured and he soon lost power, only to see it restored by Claudius in $41 \mathrm{CE} .{ }^{17}$ Antiochus then embellished the already established Greek cities on the coast with a goal of aggrandizing his own reputation while diminishing that of local elites. ${ }^{18}$ He allowed such cities - among them Selinos, Anemurion, Kelenderis, Korykos, Lakantis, and Elaiussa Sebaste - to mint coins, helping to solidify their role as primary urban centers in his kingdom. ${ }^{19}$ As all these cities are coastal, Antiochus seems to have been looking outward economically, not inward, particularly with respect to trade. His rule over western Rough Cilicia, however, was not complete, as Seleucia on the Kalykadnos was not under his control. ${ }^{20}$

Antiochus also founded several new cities within the client-kingdom. Although the ancient sources do not mention their foundation, their dynastic nomenclature makes it fairly certain that Antiochus was responsible. Some $30 \mathrm{~km}$ northwest of Antioch, he founded Iotape, which he named after his sister-wife or (less likely) his daughter. ${ }^{21}$ The other new coastal city that Antiochus created, Antioch, is eponymously named. Although their precise foundation dates are undocumented, it seems untenable that Antiochus could have established these cities in the short period when he was king under Gaius, a reign that probably lasted only a few months. It is more likely that they were founded after he returned to the throne in $41 \mathrm{CE}$. Eirenopolis, Germanicopolis, and Philadelphia, high into the middle reaches of the Taurus mountains, are also believed to

13 Strabo 14.5 .3 ( $\$ 669)$ and 14.5.6 (§671). For recent discussion of Roman rule in Rough Cilicia following the dissolution of the pirates, see Rauh et al. 2009, 276-85. Also see Hild and Hellenkemper 1990, 32-33; Borgia 2013.

14 For a recent discussion of Roman policy, see Hekster 2010.

15 Cass. Dio 54.9.2; Tac. Ann. 6.41. On Antiochus IV, see Sullivan 1977; more recently, see Borgia 2013.

16 Cass. Dio 59.8.2; Rauh et al. 2009, 278-79.

17 OGI 411; Cass. Dio 60.8.1; Joseph. AJ 19.276. Borgia $(2013,89)$ cites Cass. Dio 60.8.1, inferring that restoration of power in Rough Cilicia occurred concurrently with the resumption of power in Commagene.

18 Borgia 2013, 91.

19 Jones 1971, 211; Sullivan 1977, 787.

20 Borgia 2013, 91. Borgia argues that Antiochus's authority was focused mainly along the coast, as it is those cites that appear to have been the beneficiaries of his largesse.

${ }_{21} \quad$ Hild and Hellenkemper 1990, 275-76. For Iotape as his sister-wife, see Macurdy 1936. 
be his foundations, ${ }^{22}$ presumably part of a concerted effort - with Roman help - to suppress the marauding tribes in the even higher elevations of the Taurus range. ${ }^{23}$ His good relationship with Rome is perhaps best underscored by his role in defusing an insurrection in $52 \mathrm{CE}$, when the Cietae laid siege to Anemurion. ${ }^{24}$ Although the Roman military was poised to end the situation with force, Antiochus solved the problem through diplomacy. The foundations of the three mountainous cities within Isaurian territory should be seen in the context of containment. ${ }^{25}$

Antiochus presumably continued to maintain control of his realms by virtue of his good relationships with both Claudius and Nero. His rule in Cilicia Tracheia lasted for 31 years, but it came to an end in $72 \mathrm{CE}$ when Vespasian removed him from his rule of both Commagene and Cilicia. ${ }^{26}$ Emanuela Borgia suggests that his removal was not due to Vespasian's displeasure with his performance, but because of a broader political strategy of removing client-kings to allow Rome to exert direct authority over its provinces. ${ }^{27}$ As evidence of this policy, the province of Cilicia was definitely formed in $72 \mathrm{CE}^{28}$

No ancient source specifically records that Antiochus founded an Antioch (or Iotape); it is only the confluence of various threads of circumstantial evidence that led Beaufort (and

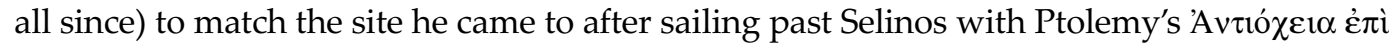
Kpó $\gamma \omega$. These threads are:

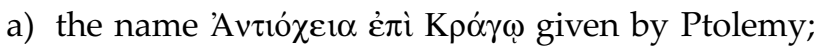

b) the correction of Ptolemy in the Stadiasmus, which gives the proper sequence of cities along the coast; $;{ }^{29}$

c) the association of Appian's epithets Kragos and Antikragos with the distinctive topographical features of the large ancient Roman city located within the modernday village of Güney; ${ }^{30}$ and

See Jones 1971, 209-11 with n. 36; Lenski 1999, 435; Rauh et al. 2009, 279; Borgia 2013, 91.

23 These indigenous peoples were collectively referred to as the Isaurians or "mountain Cilicians." There are four recorded Isaurian tribes: Homonadenses, Cietae, Cennatae, and Lalasseis; see Rauh et al. 2009, 261-62 with n. 19, and 276-79; Rauh et al. $(2009,279)$ further suggest that these foundations were meant to "solidify the eastern border against the Parthians." Townsend and Hoff (2004) show that additional Roman settlements such as Lamos and Asar Tepe, in the lower elevations behind the coast, acted as further buffers between the Rome-dominated seaboard and the tribal areas farther inland.

24 Tac. Ann. 12.55.1-2; Borgia 2013, 90.

25 See Rauh et al. 2009, 279.

26 Suet. Vesp. 8; Joseph. BJ 7.219-43, esp. 238. Ramsay $(1890,373-74)$ suggests that Vespasian gave control of Iotape to Antiochus's daughter Iotape and her husband, Alexander; based on a problematic passage in Josephus (AJ 18.5.4), this supposition is not generally accepted; see now Borgia 2013, 90.

$27 \quad$ Borgia 2013, 90.

28 It can be argued that Cilicia was nominally a province of Rome as a result of the conquest of the pirates by Pompey in $67 \mathrm{BCE}$, although it appears that a large section of the province - namely the mountainous western section - was difficult to control. It is also possible that Cilicia was formed as a province even earlier, c. 100 BCE, as an inscription from Knidos suggests; see Hassall et al. 1974, 209.

29 On the Stadiasmus, see above, n. 4. The list in the Stadiasmus proceeds from west to east, the opposite direction from that of Ptolemy.

30 Strabo also uses the name Kragos but without reference to an Antikragos; it is the combination of the two that provides the site's distinctive topographical character. 


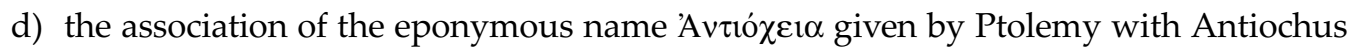
IV of Commagene. Ptolemy is crucial in this linkage; he is the only source to combine

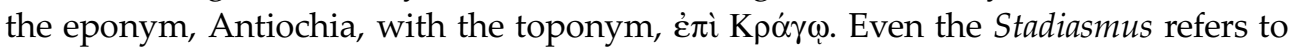
the site by its epithet only. ${ }^{31}$

Ptolemy appears to be yet more singular: numismatic and epigraphical evidence gives

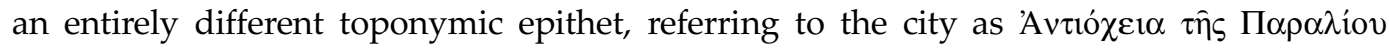
(Antioch-on-the-Coast). The reverses of the city coins carry the name in the genitive plural,

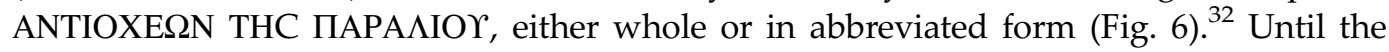
recent excavations, which have discovered more examples, these coins numbered fewer than 50 specimens, $^{33}$ ranging in date from Hadrian to Gallienus, with the majority in

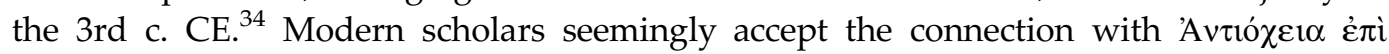

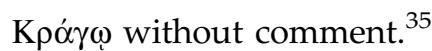

This name also has been recognized on two inscriptions found recently. One inscription, built into a Late Roman/Byzantine wall on the acropolis, belongs to a statue base dedicated by the Demos to Sabina, wife of Hadrian (Fig. 7). ${ }^{36}$ Although only part of the inscription survives, the complete restoration of the city name is unequivocal. (The complete description of this inscription is provided in the second section.)

The other, a small fragment of a molded stele, reused in a late wall near the Bouleuterion, contains the truncated name of the city. ${ }^{37}$ In both cases, the complete city

More specifically, as $\chi \omega \rho$ íov Kpóyov. The term chorion in the Stadiasmus appears to mean an inhabited place and may include cities and towns; similar forms are used for Nephelis.

32 On the coins, see Imhoof-Blumer 1895, 287-88; Hill 1900, xxxviii-xxxix. In light of the coins, Hill referred to the city as "Antiochia $\tau \hat{\eta} \varsigma$ П $\alpha \rho \alpha \lambda$ iov," yet identified the city as Antiochia ad Cragum according to convention. For recent discussion of the reverse type of the Antioch coins, see Levante 1991, 205-7. The recently excavated coins have not been studied yet.

33 The coins of Antioch have recently been collected in RPC Online (Mairat et al. 2005-): https://rpc. ashmus.ox.ac.uk/search/browse?city_id=26, accessed 3 December 2020.

34 Perhaps the cessation of coin minting at the time of Gallienus is not coincidental. It was during his reign in 260 CE that the Sassanid Persians under Shapur raided the cities along the Cilician coast, including Antioch; Res gestae divi Saporis 2, 27-31 (for the text, see Maricq 1958). See also Dodgeon and Lieu 1994, 57; Rauh et al. 2009, 301.

35 Head 1911, 717. Other scholars have followed suit, e.g., Jones 1971, 211, one of the few modern scholars to use "on the Sea" in preference to ad Cragum, but with no comment. The most recent comprehensive consideration of Antioch, by Hild and Hellenkemper 1990, 191-93, ignores the civic coinage in relation to the city's name. This paper restricts itself to the name of Antioch from the 1st c. BCE to the 2nd c. CE. The nomenclature of the city in the Late Roman and Byzantine periods continued to evolve: e.g., Antiochia in Isauria (Hieron. 709.3), Antiochia of

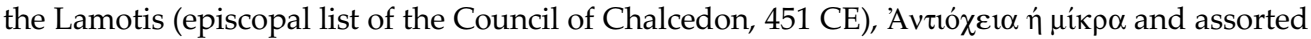
derivatives intended to distinguish it from "greater" Antioch on the Orontes. For these and additional references, see Rauh et al. 2009, 255 n. 10; Hild and Hellenkemper 1990, 191-93, sv. "Antiocheia am Kragos"; Müller 1855, 486, §200. These later appellations form another interesting, but separate chapter in the history of the city's nomenclature.

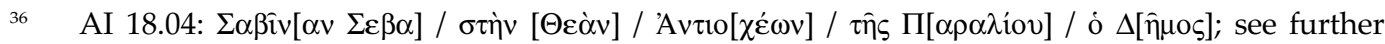
below.

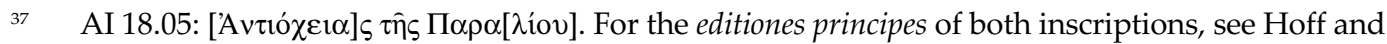
Howe 2020. 


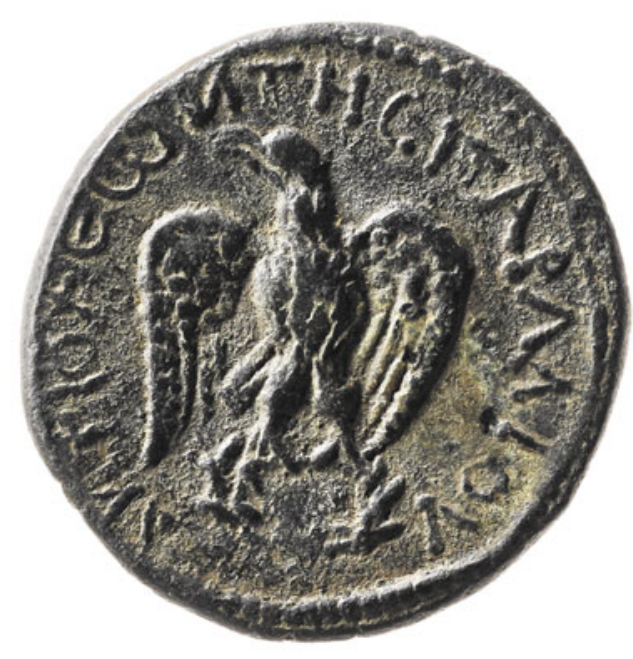

Fig. 6. Antiochia ad Cragum. Valerian (117-38 CE), bronze alloy. Rev. Eagle, frontal, head turned towards left; ANTIOXESN THC ПAPAAIOY. BM 1979,0101.2561. (C) The Trustees of the British Museum.)

name parallels the numismatic evidence:

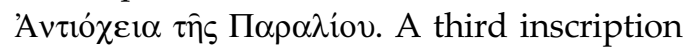
is relevant here, one noted by Bean and Mitford within the village of Güney. The final line of the inscription honors an embassy from the city to an emperor:

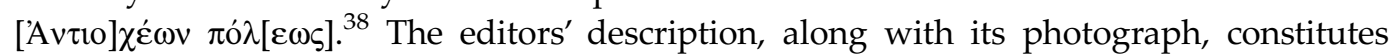
its only surviving record. Since neither epithet is present, it seems that the use of an epithet was not necessarily required; "the city of the Antiochenes" appears sufficient. These inscriptions represent the only known use of the city name on stone. The two inscriptions that include an epithet have the toponym $\tau \hat{\eta} \varsigma \Pi \alpha \rho \alpha \lambda$ iov, as do coins, suggesting that this

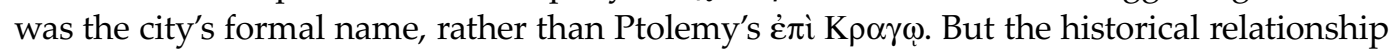
between the two names remains intriguing. It should also be emphasized that neither coins nor any inscription known so far bear the epithet غ̇ $\pi \dot{i}$ K $\rho \alpha \gamma \omega$.

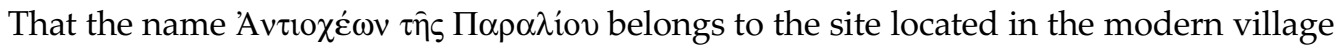
of Güney is beyond dispute. Although circumstantial, and despite the lack of numismatic or epigraphical examples, the evidence for the association of this same site with the

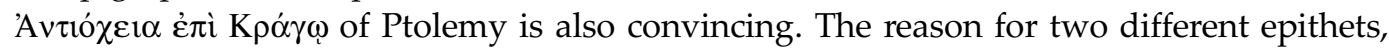
however, is less clear. The toponym Kragos appears to have identified the locale before it achieved urban status. From the late Hellenistic era or earlier, the Kragos, with its prominent cliffs, promontory, and anchorage, all clearly visible from the sea, was well known,

38 Bean and Mitford 1965, 41, no. 44. See also Robert and Robert 1967, 552, no. 625; Hagel and Tomaschitz 1998, 41-42 AntK 20. 
especially while serving as a pirate enclave. ${ }^{39}$ The second epithet, $\tau \hat{\eta} \varsigma$ П $\alpha \rho \alpha \lambda$ íov, appears only on stone and coins from the 2nd c. CE onwards. Perhaps when Antiochus IV founded his eponymously named city, he created a new, independent epithet, $\tau \hat{\eta} \varsigma \Pi \alpha \rho \alpha \lambda$ íov, to serve

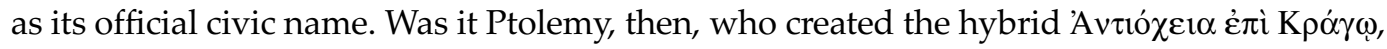
bringing together the eponymous name with the old toponym? The contrasts in medium and type of document are curious: written, secondary sources, on the one hand, speak of

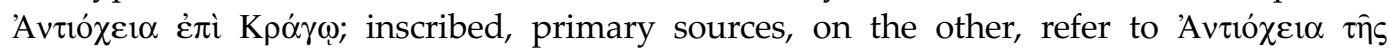

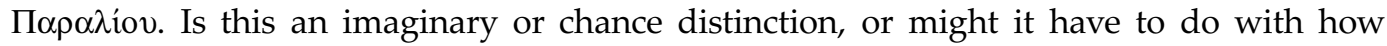
the city was known to foreigners versus the local administration and inhabitants? Whatever may be the case, it appears to be an example of "old habits die hard," for the

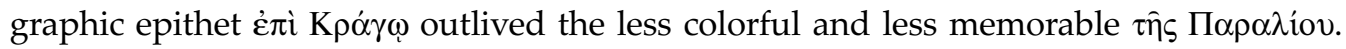

\section{Antioch honors Hadrian and Sabina}

Among the inscriptions described in the previous section was a statue base (AI 18.04) honoring Sabina, wife of Hadrian. Also discovered in 2018 was another statue base, this one dedicated to Hadrian, which had been reused as wall material for a Late Antique structure. These two statue bases represent the only known imperial dedications yet found in the city. But they are hardly unique; similar dedications have turned up in other cities in the region. This section argues that, taken as a group, the inscriptions may mark the itinerary of the imperial couple as they made their way from Egypt to Athens in $131 \mathrm{CE}$.

Statue base of Hadrian (AI 18.06; Fig. 8), 117-38 CE

Marble statue base reused in east wall of Peristyle Building. Remains in situ. Base 1. $0.65 \mathrm{~m}$; base w. $0.40 \mathrm{~m}$; letter h. $0.03 \mathrm{~m}$.

Text

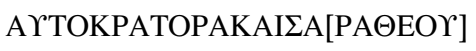

[TPA]IAN[OYПAPEIKOYYION]

[OEORNEPOYATISNON]

T[PAIANONA $\triangle \mathrm{PIANON]}$

$5 \quad[\Sigma E B A \Sigma T O N T O N K Y P I O N K A I]$

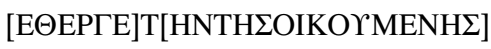

$[\mathrm{O} \Delta \mathrm{HMO} \Sigma]$

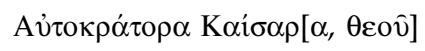

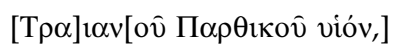

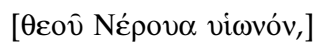

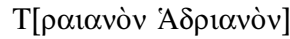

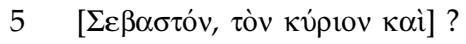

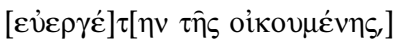

[ó $\delta \bar{\mu} \mu \mathrm{os}]$

Publications: Unpublished.

Commentary: Much of the inscription has been worn away; only the first two words of line 1 are legible enough to warrant a clear reading. Line 2: only IAN is readable but enough to allow a reconstruction of TPAIANOr. Lines 3-6: we reconstruct the rest of the text to be the same as that on the Kestros 1 base (see below). We observe on line 6 a tau whose position would fit with EUERTETHN of Kestros 1.

39 It is not unreasonable to consider the possibility that the two names might, in fact, reflect two separate communities operating in close proximity: the higher site referred to as the Kragos,

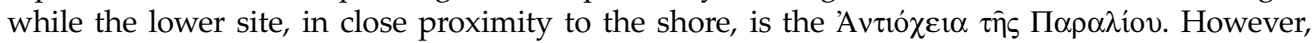
careful survey of the areas closer to the shore have revealed no evidence of civic architecture, nor is the steep terrain conducive to construction. 


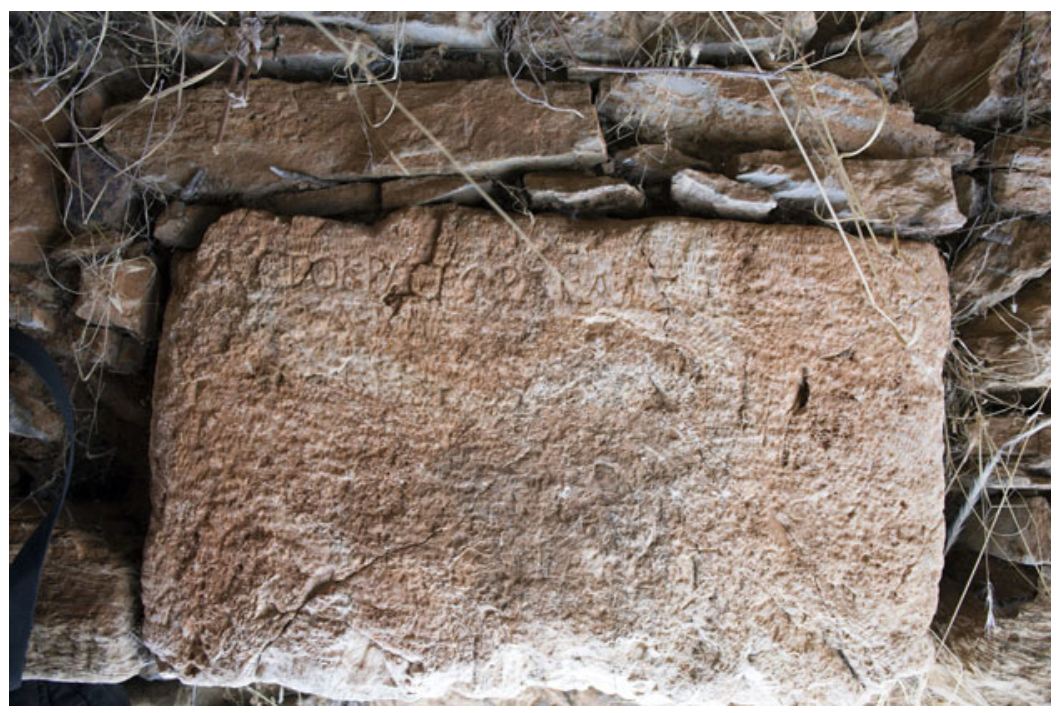

Fig. 8. Antiochia ad Cragum Inscription 18.06, embedded in east wall of Peristyle Building. (Courtesy ACARP archives.)

Statue base of Sabina (AI 18.04; Fig. 7), 128-37 CE

Embedded as spolia in the northwest wall of Building 5 on the acropolis are five fragments of a statue base of white marble. The largest fragment contains the upper left half of the block's dedicatory inscription; the fragment is split laterally, preserving much of the original lettering. The exposed face shows heavy pitting due to weathering. Remains in situ.

Fragment 1. 0.65 m; w. 0.20 m; letter h. 0.027 m.

Text

\begin{tabular}{|c|c|}
\hline$\Sigma$ ABIN[AN $\Sigma$ EBA] & $\Sigma \alpha \beta \bar{\imath} v[\alpha \nu \Sigma \varepsilon \beta \alpha]-$ \\
\hline$\Sigma \mathrm{THN}[\Theta \mathrm{EAN}]$ & 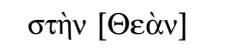 \\
\hline ANTIO $[\mathrm{XE} \Omega \mathrm{N}]$ & 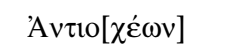 \\
\hline ТН $\Sigma \Pi[$ АРА $\Lambda$ IOҮ] & $\tau \hat{\tau} \varsigma$ $\Pi[\alpha \rho \alpha \lambda i ́ o v]$ \\
\hline $\mathrm{O} \Delta[\mathrm{HMO} \Sigma]$ & $\dot{o} \delta[\hat{\eta} \mu \circ \varsigma]$ \\
\hline
\end{tabular}

Publications: Hoff and Howe 2020.

Commentary: The late wall in which the statue base fragments were incorporated is located at the western extremity of the Acropolis, which consists of a Late Roman/Early Byzantine settlement with a series of churches, outbuildings, and towers. Sabina is here spelled without an epsilon, a departure from the normal nomenclature but not unknown. At Ephesos there is an honorific inscription for Sabina, where her name is similarly spelled without an episilon ( $\Sigma \alpha \beta i v \alpha v$; IEph 278=McCabe 1991, 1010). The date of the inscription at Antioch can be placed after $128 \mathrm{CE}$, when Sabina was given the honorific title of Augusta $\left.(\Sigma \varepsilon \beta \alpha \sigma \tau)^{\prime}\right)$, probably at the same time that Hadrian accepted the title pater patriae. ${ }^{40}$ Our restoration in line 2 of $\theta \varepsilon \alpha \dot{v} v$ following $\Sigma \varepsilon \beta \alpha \sigma \tau \eta$ is speculative, but the word conforms to the need for similar spacing in lines 2 and 3 based on parallel construction (eight and nine 
Table 1.

Distribution of Hadrianic statue bases in western Rough Cilicia

City name

\# Hadrian bases

\# Sabina bases

Antiocha ad Cragum 1

Charadros

Iotape

Kestros

Lamos

1

Nephelis

Selinus

Syedra

Sources: Iotape: Paribeni and Romanelli 1914, 181-82, no. 128. Kestros 1: Bean and Mitford 1970, 159, no. 163; AÉpigr 1972, 648; Hagel and Tomaschitz 1998, 149-50 Kes 17. Kestros 2 (with Sabina): Bean and Mitford 1970, 159-60, no. 164; AÉpigr 1972, 649; Hagel and Tomaschitz 1998, 150 Kes 18. Lamos: AÉpigr 2005 (2008), 1549; SEG LV 1518; Rauh et al. 2018.

characters, respectively). The use of $\theta \varepsilon \alpha$ may be in reference to Hera as a counterpart to Hadrian Olympios. Sabina is described as $\theta \varepsilon \alpha \dot{\alpha}$ in several inscriptions at Ephesos, but not elsewhere. $^{41}$

These two inscriptions can now be added to the corpus of honorific statue bases dedicated to Hadrian and Sabina that have so far been identified in western Rough Cilicia. ${ }^{42}$ Table 1 indicates the distribution of inscribed Hadrianic statue bases in the region among the known Roman-era cities (see also Fig. 9). The table shows that half of the urban sites (poleis) in the region contain at least one Hadrianic base, and in two cities there are paired bases to Hadrian and Sabina. Several of the bases are recorded to have been found in situ or close to in situ. In all of these cases the original locations appear to have been within or close to an imperial temple or a walled enclosure for the purpose of displaying imperial statuary. For example, at Iotape the statue base was observed by Bean and Mitford as standing in the "small temple, seemingly that of Trajan." 43 Hadrian's nomenclature is normative, although the text does refer to him as "despot of the earth and sea." 44

Kestros, approximately $14 \mathrm{~km}$ northwest of Antioch, sits atop a ridge (376 m a.s.l.) approximately $1 \mathrm{~km}$ from the coast. Inscriptions at the site were earlier studied and published by Bean and Mitford, who visited on several occasions in the 1960s. They identified a structure at the southern extremity of the visible ruins as an imperial temple that included no fewer than six statue bases. The base centered at the rear of the cella honored Vespasian, leading Bean and Mitford to assume that the temple belonged to him; other

$41 \quad$ McCabe 1991, 1006; IEph $278=$ McCabe 1991, 1010; $\theta \varepsilon \alpha$ is is restored for Ephesos inscriptions 1002 and 1011. See also Brennan 2018, 143-44, who notes that Ephesos is the only city that honors Sabina as $\theta \varepsilon \alpha ́$ in a public dedication.

42 The region under consideration extends from the Sedre river (approximately $15 \mathrm{~km}$ east of Alanya), near the traditional border with Pamphylia at the northwest, to Charadros at the southeast. On the question over the boundary between Pamphylia and Cilicia, see Rauh et al. 2009, 255 n. 5. This boundary places the city of Syedra within Cilicia.

43 Bean and Mitford 1965, 27 and n. 47 (text revision of Paribeni and Romanelli); see also Hagel and Tomaschitz 1998, 128-29 Iot 14.

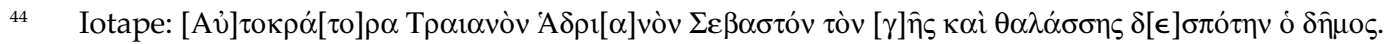




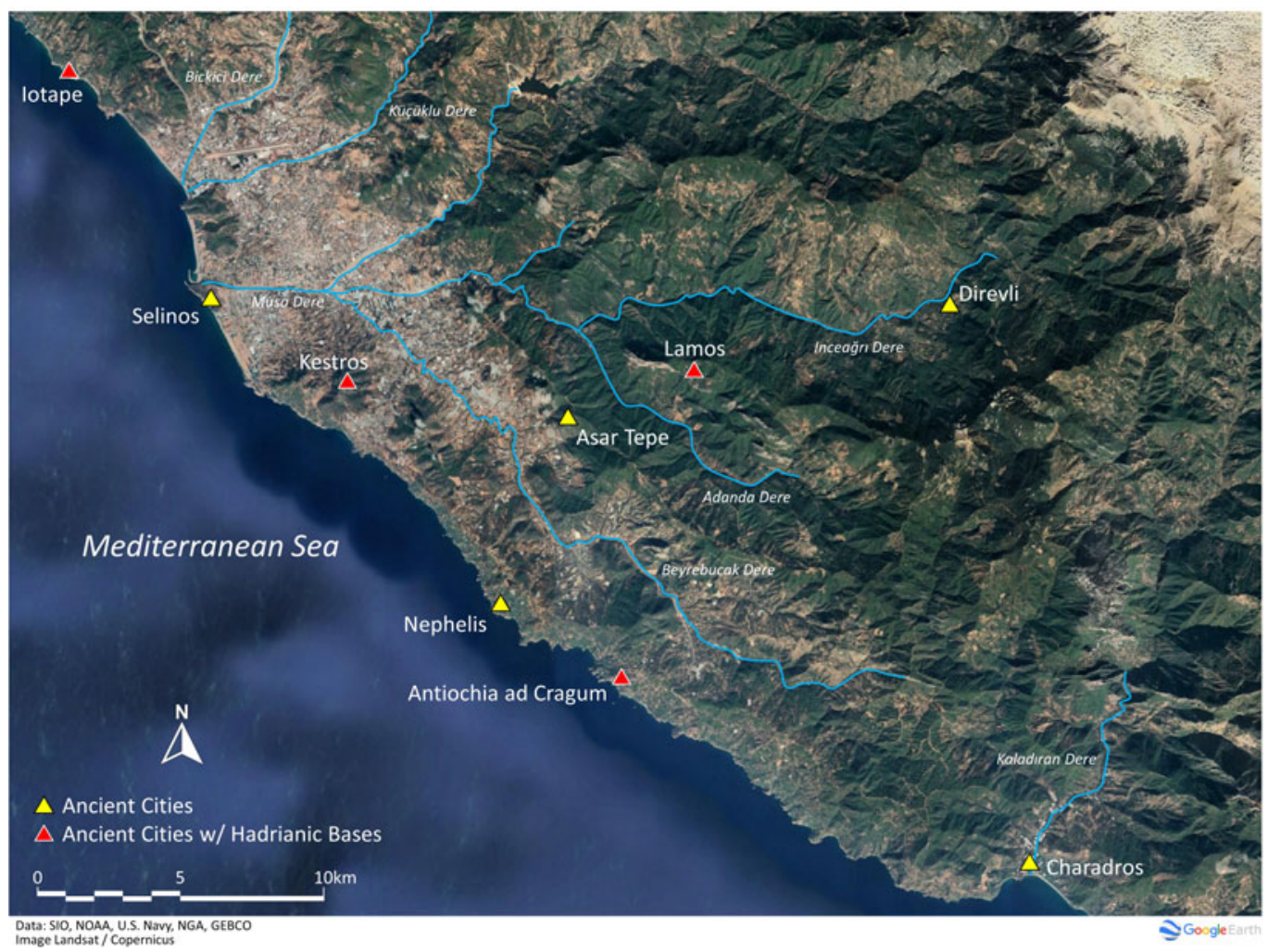

Fig. 9. Major sites of western Rough Cilicia with distribution of Hadrianic bases. (Map by B. Cannon.)

bases along the side walls belonged to Titus, Nerva, and Trajan. ${ }^{45}$ The final two bases closest to the doorway were dedicated to Hadrian; that on the east side also contains a dedication to Sabina. The two Hadrian statues thus stood facing each other.

Kestros 1 (west base)

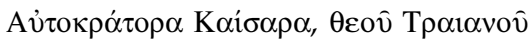

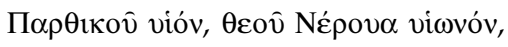

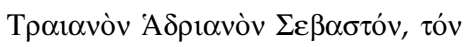

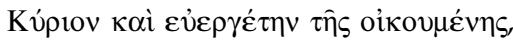

5

ó $\delta \hat{\eta} \mu \mathrm{os}$.

Kestros 2 (east base)

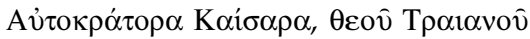

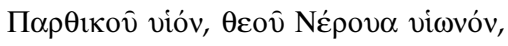

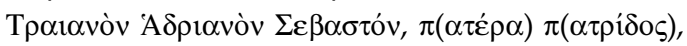

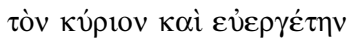

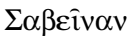

$\Sigma \varepsilon \beta \alpha \sigma \tau \eta \dot{v}$

5 ó $\delta \hat{\eta} \mu \mathrm{s}$.

Bean and Mitford (1970, 157-60, nos. 159-64 and fig. 7) provide a sketch of the layout of the inscribed bases within the temple. Rauh et al. $(2009,290)$ label this temple as belonging to the imperial cult. See also Price 1984, 161. The site was surveyed in 2004 as part of the RCSP; the plan, which includes the temple to Vespasian and a second one facing it, has not yet been published. 
Bean and Mitford proposed that the two dedications were made at different times. They posit that Kestros 1 was dedicated at the beginning of Hadrian's reign (c. $117 \mathrm{CE}$ ), while Kestros 2 dates no earlier than $128 \mathrm{CE}$, when Hadrian received the title of pater patriae. They further suggest that Kestros 2's dedication may have been prompted by a visit to the region by Hadrian, a suggestion echoed by Simon Price. ${ }^{46}$ Kestros 2 is composed of a single block of marble, $1.64 \mathrm{~m}$ long, on which statues of both Hadrian and Sabina stood. The nomenclature of the Antioch base exactly matches that of both Kestros examples up to the word $\Sigma \varepsilon \beta \alpha \sigma \tau$ óv. From this point there is a departure of nomenclature to allow for custom phrasing.

The site of Lamos is situated atop a long ridge that parallels the coastline, approximately $11 \mathrm{~km}$ inland (see Fig. 2). The statue base dedicated to Hadrian was discovered by the Rough Cilicia Survey Project in 2001 within a 36-m-long, rectangular enclosure to the northeast of and overlooking the agora. ${ }^{47}$ Several sites within the region contain such walled enclosures, which appear to have been constructed for the express purpose of displaying statues, many of them imperial. ${ }^{48}$ The text of the inscription has appeared in Année Épigraphique and SEG, but as the inscription has never been discussed, it is worthwhile reproducing it here: ${ }^{49}$

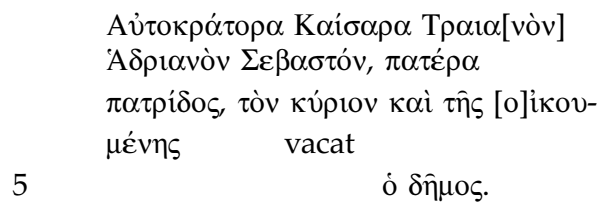

Again, the nomenclature follows common protocols for other dedications to Hadrian found in the region. He is described as "Lord of the inhabited world," a similar title to that found on the Kestros examples, and echoing Iotape's "despot of the land and the sea." He is named as pater patriae, thereby suggesting a terminus post quem of $128 \mathrm{CE}$.

Imperial visits to provincial cities were often the catalyst for various sorts of reciprocal dedications such as these, part of the practice of euergetism in the Roman world. ${ }^{50}$ The Historia Augusta (13.6-7) mentions that Hadrian dedicated temples and altars during his travels in the east; and Cassius Dio reports (69.5.2-3) that cities Hadrian visited often received imperial benefaction. It is well known that the peripatetic emperor toured most of the provinces of the empire, and much has been written about his itineraries. ${ }^{51}$ Although the literary sources are silent regarding a visit to Cilicia during his third itinerary, we know one must have occurred - or was expected to have occurred - as coins commemorating it (Adventus) were issued, probably in Tarsus, with Hadrian on the obverse and the

$46 \quad$ Bean and Mitford 1970, 159-60; Price 1984, 161.

$47 \quad$ Rauh et al. 2009, 288 (table 5) and 292.

48 On statuary displays within walled enclosures, see Rauh et al. 2009, 292.

49 AÉpigr 2005 (2008) 1549; SEG LV 1518. The discovery of the inscription is noted by Rauh et al. 2009, 291.

50 Magie 1950, 620-21. Euergetism has long been studied; for a recent cogent analysis from an anthropological viewpoint relating to the region in question here, see Wandsnider 2013.

51 E.g., Henderson 1923, 283-94; Magie 1950, 620-21; Halfmann 1986; Syme 1988; Birley 1997; Boatwright 2000. For a contrary opinion regarding the dedication of bases as an indicator of imperial visits, see Højte 2000. 
personification of Cilicia on the reverse. ${ }^{52}$ The date when Hadrian appeared in Cilicia has been open to question, but recent scholarship appears to have settled on $131 \mathrm{CE}$, during his westward journey from Egypt. ${ }^{53}$

If the date of the trip is generally accepted, the exact itinerary is not. ${ }^{54}$ The only sure signposts are that Hadrian spent the winters of 130/1 CE in Alexandria and 131/2 CE in Athens. This time frame therefore gave him just over six months of optimum weather to make the journey. As for stops en route, dedications found in the cities of Cilicia and elsewhere provide evidence of the imperial entourage as it proceeded along the coastline, first in the Levant, then to the south Asia Minor coast, and then along the Aegean coast in Asia. $^{55}$

Scholars have also differed on whether Hadrian traveled by land or by sea. ${ }^{56}$ Clearly, the sea route was more direct and had the advantage of avoiding the difficult mountainous terrain. T. Corey Brennan suggests a hybrid approach for the itinerary; westward progress occurred by the sea route, with stops at predetermined locations and occasional forays inland to visit more remote locales. ${ }^{57}$ Surviving documentation suggests that, as might be expected, organizing an itinerary for an emperor and retinue required considerable advance planning. ${ }^{58}$ The destinations would have been announced perhaps months beforehand, in order to provision the large entourage, but also to allow provincials to prepare for the ceremony of the imperial adventus. A sea voyage along the coast must have involved a sizable contingent of ships, and these would have required suitable anchorages convenient to the cities where the emperor could stop. The evidence for harbors in western Rough Cilicia is limited. ${ }^{59}$ Iotape had a naturally enclosed harbor, but it was very small. Selinos preserves no remains of a constructed harbor per se, but the Hacımusa river, which empties into the sea at Selinos, is thought to have been canalized before the time of Trajan, suggesting that ships did put into port there. ${ }^{60}$ A number of sources refer to Charadros as a port. ${ }^{61}$ Antioch does not appear to have had a constructed harbor but did possess a relatively

52 Struck 1933, pls. 3, 16; Toynbee 1934, 69; BMCRE III 490; Birley 2003, 432 n. 57. On Hadrian's journeys, see note 53 .

53 For Hadrian's journeys and their dates, see Henderson 1923, 294; Magie 1950, 620-21; Halfmann 1986, 208; Syme 1988, 164-65. See also Bean and Mitford 1970, 160; Brennan 2018, 138.

54 Halfmann 1986; von Mosch and Klostermeyer 2015, 285-326; Brennan 2018, 131-41.

55 For evidence regarding this itinerary, see Halfmann 1986, 208; Brennan 2018, 138-44.

56 Land route: e.g., Bean and Mitford 1970, 160; sea route: e.g., Halfmann 1986, 208; see also Syme 1988, 164.

$57 \quad$ Brennan 2018, 138-41.

58 E.g., Philo, Leg. 33.252-53; see also Millar 1977, 28-40, esp. 35: “The movement of an emperor was thus a social and economic event of significant proportions."

59 R. L. Vann attempted to form a simple typology of harbors and anchorages in the region. Although he included discussion of two small inlets at Antioch that could have served as pirate anchorages, he omitted from his typology the main anchorage to the west of the Antikragos that was certainly used for all seaborne shipping; see Vann 1997.

60 As discussed below, Trajan's body was likely cremated near to the river's edge and a temple was subsequently constructed on the same location. The site is clearly in the river's floodplain. The temple's construction would not have occurred unless the river was made manageable through canalization; blocks used to channel the current are still visible (although no longer in situ) along the river's embankment.

61 Rauh et al. 2009, 14 with nn. 14 and 15. 
sheltered anchorage. Of these sites, Hadrianic dedications have been found only at Iotape and Antioch (Table 1); of the two, Antioch (the larger city) would have been the more logical choice for an imperial visit. One can imagine a scenario where the emperor disembarked at Antioch, and then either met with embassies from other communities in the area, including inland cities such as Lamos and Kestros, or else visited those communities directly by traveling overland, in the hybrid fashion suggested by Brennan.

All indications are that Sabina accompanied Hadrian. There is no doubt that she was in Egypt with her husband, as she left behind a graffito carved on one of the statues of Memnon in the necropolis of Thebes as testimony to her presence. ${ }^{62}$ Scholars who claim Sabina's presence in the entourage point to dedications in Asia Minor, in both single or joint dedications along with Hadrian, including Kestros in Rough Cilicia (referenced above); Magydos in Pamphylia; Rhodiapolis, Patara, and Tlos in Lycia; Tralles in Caria; Hierapolis in Phrygia; Pisidian Antioch; and Magnesia in Ionia. ${ }^{63}$ Clearly, the closest relevant example to the Antioch dedication is the double dedication to Hadrian and Sabina at nearby Kestros. The formula is simpler than that found at Antioch, with Sabina referred to only as Sebaste. But the inscription adds to the considerable epigraphic testimony that the empress was present for the journey.

Possibly accompanying the imperial couple was Julia Balbilla, an acclaimed poet and a member of the Roman elite. ${ }^{64}$ We know that she was present along with Hadrian and Sabina in Egypt because she too left her mark on the Colossi of Memnon with verse graffiti that have long been known and studied. ${ }^{65}$ It appears she had been a friend of Hadrian and Sabina perhaps for several decades, along with her brother, C. Iulius Antiochus Epiphanes Philopappos. ${ }^{66}$ Since the entourage was headed to Athens, it seems reasonable to assume that Balbilla, like her brother a resident of that city, would have accompanied Hadrian and Sabina. Moreover, Balbilla would have had a familial interest in visiting western Rough Cilicia, as it was her grandfather King Antiochus IV of Commagene who founded Antioch and nearby Iotape shortly after $41 \mathrm{CE}{ }^{67}$ There is no evidence that Balbilla had ever visited the region previously, and thus we can imagine the citizens of Antioch being as excited to greet Balbilla as they were to host Hadrian and Sabina in the city, a visit that must have been celebrated by Antioch's citizenry, especially in the accompaniment of the imperial couple.

Another example of the effect that Hadrian's visit in $131 \mathrm{CE}$ had on the region may be seen on coinage. The mechanism that provided the privilege of minting coins by provincial cities is not well understood, but, in the case of at least some of the cities of western Rough

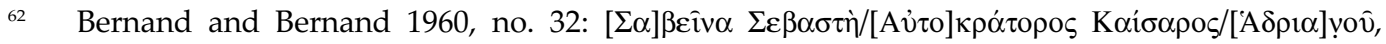

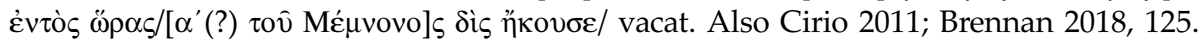

63 For a review of these dedications, see Brennan 2018, 139-41.

64 Not much is known about Julia Balbilla, but her pedigree has been reconstructed: see Sullivan 1977, 796-97; Spawforth 1978, 252; Kleiner 1983, 17 and 95.

65 On Balbilla and the Memnon inscription, see Brennan 1998; Rosenmeyer 2008; Cirio 2011; Rosenmeyer 2018, 141-54; Brennan 2018, 127-37 (with full bibliography).

66 Kleiner $(1983,95)$ suggests that Balbilla may have been responsible for the construction of her brother's well-known tomb, the Philopappos Monument, and is possibly interred within it herself.

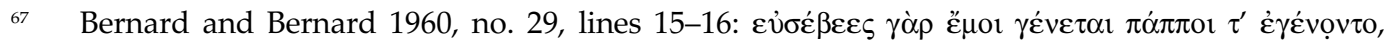

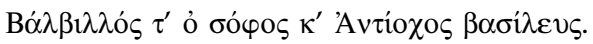


Cilicia, it may be that the emperor himself granted this privilege. ${ }^{68}$ Prior to Hadrian, the only cities in the region that minted coins were Anemurion and Selinos. Beginning with Hadrian, however, the cities of Antioch, Iotape, Kestros, and Lamos minted coins. ${ }^{69}$ Curiously, no coin of Hadrian survives from Kestros, but there is a single issue that features Sabina, with the inscription $\Sigma$ ABEINA $\Sigma$ EBA $\Sigma T H$, the same minimal titulature as on the statue base from the city. ${ }^{70}$

Finally, it is tempting to think that Hadrian would have wished to visit one city in particular in western Rough Cilicia. In 117 CE the emperor Trajan suffered a medical emergency while sailing westward along the Rough Cilicia coast. The ship put into the nearest anchorage, which turned out to be Selinos, and it was there that Trajan died. Recently it has been argued that Trajan's body was cremated while still at Selinos, and subsequently the ashes were carried to Rome to be deposited inside the Column of Trajan. ${ }^{71}$ It is further argued that a temple was constructed over the exact location of the ustrinum to honor the deceased emperor. ${ }^{72}$ One can imagine that Hadrian would have insisted on viewing the location where his adoptive father literally became divus, and where he himself was elevated to the emperorship. The name of Selinos was, in fact, changed to Traianopolis to reflect the honor given to it by Trajan's death within its walls. ${ }^{73}$

Western Rough Cilicia would have made for some nostalgic and poignant memories for Hadrian, Sabina, and Balbilla, perhaps providing sufficient enticement to include this rugged region in their itinerary. We can therefore imagine that, for a brief, shining moment in $131 \mathrm{CE}$, the citizenry of Antioch, a normal, everyday provincial city nestled in the far reaches of the Roman world, very possibly witnessed the power and pageantry of the Roman Empire in their own backyard.

\section{Conclusions}

Until recently, little was known about Antioch save its name and location. Now, after 15 years of excavation and study, discoveries abound. Artifacts that are found each excavation season help to shed light on the city, as well as adding to the growing knowledge of the region of Rough Cilicia more generally. This paper has presented recently discovered epigraphic material, together with the evidence of civic coinage, to demonstrate that the city's "official" name likely was quite different from what the ancient sources related,

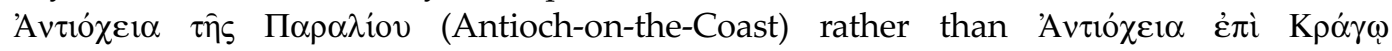

68 There have been recent attempts to address this issue: e.g., Weiss 2005.

69 See Levante 1991, who discusses the coinage of Antioch, Kestros, and Iotape. Most recently, see RPC: Antioch: vol. 3, nos. 3192-93 (https://rpc.ashmus.ox.ac.uk/search/browse?q=Antiochia+ad +cragum); Kestros: vol. 3, nos. 3188-89 (https://rpc.ashmus.ox.ac.uk/search/browse?city_id=382); Lamos: vol. 3, nos.3189A, 3190-91 (https://rpc.ashmus.ox.ac.uk/search/browse?city_id=582); Iotape: vol. 3, nos. 3181-82 (https://rpc.ashmus.ox.ac.uk/search/browse?city_id=552). Lamos's coinage apparently did not extend beyond Hadrian.

70 Kestros: $R P C$, vol. 3, no. 3188.

71 Cass. Dio 68.33.2-3; 69.1-2.3. On the death of Trajan and subsequent cremation at Selinos, see Hoff 2021, forthcoming.

72 On this temple see Winterstein 2013.

73 Ruge 1937; Levante 1990. 
(Antioch-on-the-Cliff). Again, through epigraphy, it has shown that the city honored Hadrian and Sabina, possibly in 131 CE during an imperial visit to the region.

Acknowledgments: The authors would like to acknowledge with gratitude the annual excavation and research permits granted by the Archaeological Directorate of the Ministry of Culture and Tourism of Turkey. We are grateful to private donors, the Merops Foundation, and the many students and volunteers who annually participate in the field school program that have made our research possible. For this particular paper, we would like to thank the School of Art, Art History \& Design and the Hixson-Lied College of Fine and Performing Art of the University of NebraskaLincoln for their generous subvention support, and we appreciate the comments of the anonymous reviewers. Most especially, we acknowledge John Humphrey, whose final work as editor of $J R A$ included, at least in part, this paper; we dedicate it to him, with humble thanks.

\section{References}

Arnaud, P. 2017. "Playing dominoes with the Stadiasmus maris magni: The description of Syria: Sources, compilation, historical topography." In Space, Landscape and Settlements in Byzantium: Studies in Historical Geography of the Eastern Mediterranean Presented to Johannes Koder, ed. A. Külzer and M. S. Popović, 15-50. Vienna: Akademska Knjiga.

Bean, G. E., and T. B. Mitford. 1965. Journeys in Rough Cilicia in 1962 and 1963. DenkschrWien 85. Vienna: Österreichische Akademie der Wissenschaften.

Bean, G. E., and T. B. Mitford. 1970. Journeys in Rough Cilicia 1964-1968. DenkschrWien 102. Tituli Asiae Minoris, Ergänzungsband 3. Vienna: Österreichische Akademie der Wissenschaften.

Beaufort, F. 1817. Karamania. Or a Brief Description of the South Coast of Asia-Minor and of the Remains of Antiquity. London: R. Hunter.

Bernand, A., and É. Bernand. 1960. Les inscriptions grecques et latines du Colosse de Memnon. Paris: Institut français d'archéologie orientale.

Birley, A. R. 1997. Hadrian: The Restless Emperor. London: Routledge.

Birley, A. R. 2003. "Hadrian's travels." In The Representation and Perception of Roman Imperial Power, ed. P. Erdkamp, O. Hekster, G. de Kleijn, S. Mols, and L. de Blois, 425-38. Leiden: Brill.

Boatwright, M. 2000. Hadrian and the Cities of the Roman Empire. Princeton: Princeton University Press.

Borgia, E. 2013. "The rule of Antiochus IV of Commagene in Cilicia: A reassessment." In Rough Cilicia: New Historical and Archaeological Approaches, ed. M. Hoff and R. Townsend, 87-98. Oxford: Oxbow.

Brennan, T. C. 1998. "The poets Julia Balbilla and Damo at the Colossus of Memnon." CW 91, no. 4: 215-34.

Brennan, T. C. 2018. Sabina Augusta: An Imperial Journey. Oxford: Oxford University Press.

Cirio, A. M. 2011. Gli epigrammi di Giulia Balbilla. Ricordi di una dama di corte e altri testi al femminile sul Colosso di Memnone. Lecce: Pensa Multimedia.

Cockerell, C. R. 1903. Travels in Southern Europe and the Levant, 1810-1817: The Journal of C. R. Cockerell, ed. S. P. Cockerell. London: Longmans, Green \& Co.

Dodgeon, M., and N. Lieu. 1994. The Roman Eastern Frontier and the Persian Wars AD 226-363. London: Routledge.

Hagel, S., and K. Tomaschitz. 1998. Repertorium der westkilikischen Inschriften. Nach den Scheden der kleinasiatischen Kommision der Österreichischen Akademie der Wissenschaften. DenkschrWien 265. Tituli Asiae Minoris, Ergänzungsband 22. Vienna: Österreichischen Akademie der Wissenschaften.

Halfmann, H. 1986. Itinera principum. Geschichte und Typologie der Kaiserreisen im römischen Reich. Stuttgart: F. Steiner.

Hassall, M., M. Crawford, and J. Reynolds. 1974. "Rome and the eastern provinces at the end of the second century B.C." JRS 64: 195-220.

Head, B. V. 1911. Historia Numorum: A Manual of Greek Numismatics. 2nd ed. Oxford: Clarendon Press.

Heberdey, R., and A. Wilhelm. 1896. Reisen in Kilikien. Ausgeführt 1891 und 1892 im Auftrage der Kaiserlichen Akademie der Wissenschaften. DenkschrWien 44. Vienna: C. Gerold Sohne. 


\section{New old stones at Antiochia in Rough Cilicia}

Henderson, B. W. 1923. The Life and Principate of the Emperor Hadrian. London: Methuen \& Co.

Hekster, O. 2010. "Trophy kings and Roman power: A Roman perspective on client kingdoms." In Kingdoms and Principalities in the Roman Near East, ed. T. Kaizer and M. Facella, 45-55. Oriens et Occidens 19. Wiesbaden: Franz Steiner Verlag.

Hild, F., and H. Hellenkemper. 1990. Kilikien und Isaurien. DenkschrWien 215. Tabula imperii Byzantini 5. Vienna: Österreichische Akademie der Wissenschaften.

Hill, G. F. 1900. Catalogue of the Greek Coins of Lycaonia, Isauria, and Cilicia. BMC 21. London: British Museum.

Hoff, M. 2021. "The temple of deified Trajan at Selinus (Cilicia)." In Colloquium on the Roman Emperor Marcus Ulpius Traianus, August 2017, ed. M. Sayar. Antalya: Suna \& Inan Kıraç Research Institute on Mediterranean Civilizations. In press.

Hoff, M., and T. Howe. 2020. "What's in a name? New inscriptions from Antiochia ad Cragum in western Rough Cilicia." EpigAnat 53: 163-67.

Hoff, M., R. Townsend, E. Erdoğmuş, B. Can, and T. Howe. 2015. "Antiochia ad Cragum in Western Rough Cilicia." In The Archaeology of Anatolia: Recent Discoveries (2011-2014), ed. S. R. Steadman and G. McMahon, 201-26. Newcastle upon Tyne: Cambridge Scholars.

Højte, J. M. 2000. "Imperial visits as occasion for the erection of portrait statues." ZPE 133: 221-35. Imhoof-Blumer, F. 1895. “Griechische Münzen." NC 15: 269-89.

Jones, A. H. M. 1971. Cities of the Eastern Roman Provinces. 2nd ed. Oxford: Oxford University Press. Karamut, I., and J. Russell. 1999. "Nephelis: A recently discovered town of coastal Rough Cilicia." JRA 12: 355-71.

Kleiner, D. E. E. 1983. The Monument of Philopappos in Athens. Rome: G. Bretschneider.

Lenski, N. 1999. "Assimilation and revolt in the territory of Isauria, from the 1st century BC to the 6th century AD." JESHO 42: 413-65.

Levante, E. 1990. "The coinage of Selinus in Cilicia." NC 150: 226-33.

Levante, E. 1991. "Cilician coinage." NC 151: 205-12.

Macurdy, G. H. 1936. “Iotape." JRS 26: 40-42.

Magie, D. 1950. Roman Rule in Asia Minor. Princeton: Princeton University Press.

Maricq, A. 1958. "Res gestae divi Saporis." Syria 35: 295-360.

Mairat, J., C. Howgego, and V. Heuchert. 2005-. Roman Provincial Coinage Online. http://rpc.ashmus. ox.ac.uk.

McCabe, D. 1991. Ephesos Inscriptions: Texts and Lists. Vol. 4. The Princeton Project on the Inscriptions of Anatolia. Princeton: Institute for Advanced Studies.

Millar, F. 1977. The Emperor in the Roman World. Ithaca: Cornell University Press.

Müller, K. 1855. Geographici Graeci minores. Vol. 1. Paris: Didot.

Paribeni, R., and P. Romanelli. 1914. "Studii e richerche archeologiche nell'Anatolia meridionale." MonAnt 23: 5-274.

Price, S. R. F. 1984. Rituals and Power: The Roman Imperial Cult in Asia Minor. Cambridge: Cambridge University Press.

Ramsay, W. M. 1890. The Historical Geography of Asia Minor. London: John Murray.

Rauh, N., R. Townsend, M. Hoff, M. Dillon, M. Doyle, C. Ward, R. Rothaus, H. Caner, U. Akkemik, L. Wandsnider, S. Ozaner, and C. Dore. 2009. "Life in the truck lane: Urban development in western Rough Cilicia." ÖJh 78: 253-312.

Rauh, N., L. Wandsnider, F. S. Ozaner, M. C. Hoff, R. F. Townsend, M. Dillon, M. Korsholm, and H. Caner. 2018. "Rough Cilicia Archaeological Survey Project: Report of the 2002 season." Rough Cilicia Archaeological Survey Project, 1996-2011. Paper 9, http://dx.doi.org/10.5703/ 1288284316725, accessed 2 December 2020.

Robert, J., and L. Robert. 1967. “Bulletin épigraphique.” RÉG 80: 453-577.

Rosenmeyer, P. 2008. “Greek verse inscriptions in Roman Egypt: Julia Balbilla's Sapphic voice." ClAnt 27.2: 334-58.

Rosenmeyer, P. 2018. The Language of Ruins: Greek and Latin Inscriptions on the Memnon Colossus. Oxford: Oxford University Press.

Ruge, W. 1937. “Traianopolis.” $R E^{6}$ A.2: 2087-88.

Spawforth, A. J. S. 1978. "Balbilla, the Euryclids and memorials for a Greek magnate." BSA 73: 249-60. 


\section{Michael Hoff, Rhys Townsend, and Timothy Howe}

Struck, P. L. 1933. Untersuchungen zur römischen Reichsprägung des zweiten Jahrhunderts. Vol. II: Die Reichsprägung zur Zeit des Hadrians. Stuttgart: W. Kohlhammer.

Sullivan, R. D. 1977. "The dynasty of Commagene." In ANRW, Vol. 2.8, ed. H. Temporini and W. Haase, 785-94. Berlin and New York: De Gruyter.

Syme, R. 1988. "Journeys of Hadrian." ZPE 73: 159-70.

Townsend, R., and M. Hoff. 2004. "Monumental tomb architecture in western Rough Cilicia." ÖJh 73: 251-80.

Toynbee, J. M. C. 1934. The Hadrianic School: A Chapter in the History of Greek Art. Vol. 1. Cambridge: Cambridge University Press.

Vann, R. L. 1997. "A classification of ancient harbors in Cilicia." In Res Maritimae: Cyprus and the Eastern Mediterranean from Prehistory to Late Antiquity. Proceedings of the Second International Symposium "Cities on the Sea," Nicosia, Cyprus, October 18-22, 1994, ed. S. Swiny, R. L. Hohlfelder, and H. W. Swiny, 301-19. Atlanta: American Schools of Oriental Research.

von Mosch, H.-C., and L.-A. Klostermeyer. 2015. "Ein Stempelschneider auf Reisen: Die Antinoosmedaillons des Hostilios Markellos und Hadrians Reise im Jahr 131/2 n. Chr." In KAIPOE: Contributions to Numismatics in Honor of Basil Demetriadi, ed. U. Wartenberg and M. Amandry, 285-326. New York: American Numismatic Society.

Wandsnider, L. 2013. "Public buildings and civic benefactions in western Rough Cilicia: Insights from signaling theory." In Rough Cilicia: New Historical and Archaeological Approaches, ed. M. Hoff and R. Townsend, 176-88. Oxford: Oxbow.

Weiss, P. 2005. "The cities and their money." In Coinage and Identity in the Roman Provinces, ed. C. Howgego, V. Heuchert, and A. Burnett, 57-68. Oxford: Oxford University Press.

Winterstein, C. 2013. “The Şekerhane Köşkü in Selinus: The alleged cenotaph for the Roman emperor Trajan. Preliminary report on current architectural research." In Rough Cilicia: New Historical and Archaeological Approaches, ed. M. Hoff and R. Townsend, 157-75. Oxford: Oxbow. 